\title{
PENGEMBANGAN LEMBAR KERJA MAHASISWA BERBASIS PEMECAHAN MASALAH KOLABORATIF BERBANTUAN SIMULASI INTERAKTIF PADA MATERI TERMODINAMIKA
}

\author{
Arini Rosa Sinensis ${ }^{1}$, Harry Firman ${ }^{2}$, Ida Hamidah ${ }^{3}$, Muslim $^{4}$ \\ 1,2,3,4 Program Studi Pendidikan IPA, Sekolah Pascasarjana Universitas Pendidikan Indonesia, \\ Jl.Dr.Setiabudi No. 229, Bandung 40154, Indonesia \\ 1Program Studi Pendidikan Fisika, STKIP Nurul Huda Oku Timur, Jl. Kotabaru Sukaraja, Buay \\ Madang, OKU Timur, Sumatera Selatan 32161, Indonesia \\ Email :arinirosa@student.upi.edu
}

\begin{abstract}
This study aims to develop student worksheets (LKM) based on collaborative problem solving, LKM developed with the help of interactive simulations. The research method used is design and development research (DDR). The data collection technique uses a questionnaire to assess the readability and component of collaborative problem solving in the LKM developed. The research subjects were 97 th semester students who had taken the thermodynamics course. The results showed that the readability component reached $85.7 \%$ with very good categories while the collaborative problem solving component reached 80\% with good categories. Therefore, the LKM used can be used as a media to facilitate and direct students to improve problem solving skills.
\end{abstract}

Keywords: Student Worksheets, Thermodynamics, collaborative problem solving, interactive simulations.

\begin{abstract}
Abstrak: Penelitian ini bertujuan untuk mengembangkan Lembar kerja mahasiswa (LKM) berbasis pemecahan masalah kolaboratif, LKM yang dikembangkan berbantuan simulasi interaktif. Metode penelitian yang digunakan adalah design and development research (DDR). Teknik pengumpulan data menggunakan angket untuk menilai keterbacaan dan komponen pemecahan masalah kolaboratif pada LKM yang dikembangkan. Subjek penelitian adalah 9 mahasiswa semester 7 yang telah menempuh matak uliah termodinamika. Hasil penelitian menunjukkan bahwa komponene keterbacaan mencapai $85,7 \%$ dengan katergori sangat baik sedangkan komponen pemecahan masalah kolaboratif mencapai $80 \%$ dengan kategori baik. Oleh karena itu, LKM yang digunakan dapat digunakan sebagai media untuk memfasilitasi dan mengarahkan mahasiswa untuk meningkatkan kemampuan pemecahan masalah.
\end{abstract}

Kata kunci: Lembar Kerja Mahasiswa, Termodinamika, pemecahan masalah kolaboratif, simulasi interaktif,

\section{PENDAhUluan}

Termodinamika merupakan salah satu matakuliah yang wajib dikuasai bagi mahasiswa pendidikan fisika mereka dituntut untuk memahami konsep, menerapkankonsep, serta melatih mahasiswa dalam memecahkan masalah dari menemukan masalah, menganalisis hingga memberikan kesimpulan. Permasalahan saat ini adalah konsep-konsep fisika pada termodinamika yang berkonten abstrak dianggap sulit oleh mahasiswa oleh karena itu, untuk mempermudah mahasiswa dalam memahami konsep yaitu dengan menggunakan IT yaitu (simulasi interaktif) Simulasi ini difokuskan untuk mengkritik abstrak, konsep dan fenomena kompleks dalam pendidikan sains, sehingga membantu siswa untuk belajar dengan mudah dan efektif (Akpınar, 2014). Selain itu percobaan yang sulit dilakukan di laboratorium real, 
yang umumnya disebabkan minimnya alat-alat praktikum yang memadai, dapat dilakukan menggunakan media laboratorium virtual yang dijalankan dengan komputer (Seregar, 2016). Literasi sains dan digital menjadi pendukung bagi keberhasilan peserta didik dalam bermasyarakat, peserta didik perlu dan lebih efektif menggabungkan keahlian dan gagasan mereka dalam berbagai situasi kolaboratif, memecahkan masalah, menciptakan informasi dan pengetahuan baru (Häkkinen et al., 2017).

Beberapa simulasi interaktif yang dapat diunduhsecara gratis dan dipelajari diantarany aadalah PHET simulation, Ck 12, virtual lab (http://www.vlab.co.in/broad-area-physicalsciences), Physlet (https://www.compadre.org/physlets/) beberapa simulasi tersebut sudah dilengkapi dengan Lembar kerja akan tetapi terdapat simulasi yang tidak dilengkapi dengan lembar kerja. Salah satu perangkat pembelajaran yang dapat mengaktifkan siswa adalah LKS (lembar kegiatan siswa) Puranti (2014). Oleh karena itu, untuk melengkapi pemebelajaran termodinamika berbantuan simulasi interaktif berbasis pemecahanmasalah kolaboratif, perlu dikembangkan Lembar kerja mahasiswa yang mengarahkan mahasiswa untuk berlatih dan meningkatkan kemampuan pemecahan masalah.

\section{METODE PENELITIAN}

Metode yang digunakan dalam penelitian ini adalah desain dan pengembangan penelitian (DDR) (Richey,2007). Metode ini memiliki enam tahap: identifikasi masalah, menjelaskan tujuan, desain dan pengembangan, pengujian, evaluasi hasil tes, dan mengkomunikasikan hasil. Namun, dalam penelitian ini masih dalam tahap desain LKM dan uji coba keterbacaan dan komponen pemecahan masalah kolaboratif. Subjek penelitian ini adalah mahasiswa semester 7 tahun ajaran 2018/2019 yang telah menempuh mata kuliah termodinamika. Jumlah mahasiswa untuk uji coba keterbacaan LKM adalah 9 mahasiswa dengan kategori kemampuan sedang dan tinggi. Instrumen pengumpulan data pada penelitian ini menggunakan angket. Teknik analisis data dalam penelitian ini menggunakan analisis deskriptif bedasarkan hasil analisis angket.

\section{HASIL DAN PEMBAHASAN}

\subsection{Hasil Desain LKM}

Tahap awal dalam pengembangan LKM adalah desain. Desain LKM didesain berbasis pemecahan masalah kolaboratif disesuaikan dengan simulasi interaktif termodinamika yang telah ditentukan. LKM berisi petunjuk penggunaan LKM, dilengkapi dengan waktu yang diperlukan, konsep yang akan dipecahkan, beberapa pertanyaan konsep termodinamika, refleksi yaitu dengan tujuan mahasiswa mampu merefleksi hasiltemuannya selainitu melatih mahasiswa untuk berpikir reflektif karena memiliki efekpositif pada peningkatan capaian kinerja belajar siswa kelompok (Hsieh dan Nian-Shing, 2012). Hasil desain LKM termodinamika berbasis pemecahan masalah kolaboratif ditunjukkan pada Gambar 1. 

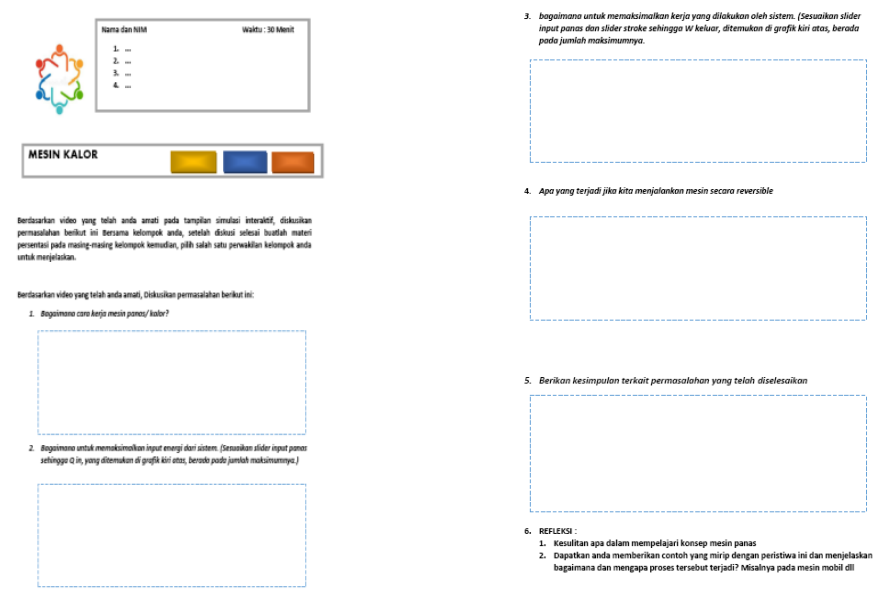

Gambar 1.Gambar Desain LKM Termodinamika

Lembar kerja Mahasiswa (LKM) yang dirancang atau didesain pada penelitian ini disesuaikan dengan langkah-langkah pembelajaran berbasis pemecahan masalah kolaboratif, akan tetapi beberapa aspek tersebut disesuaikan dengan media simulasi interaktif sebagai alat bantu pembelajarantermodinamika, yaitu; 1) kesiapan siswa dalam belajar, 2) eksplorasi masalah, 3) pemecahan masalah bersama, 4) refleksi. Pemecahan masalah kolaboratif telah digambarkan sebagai keterampilan penting bagi siswa untuk berkembang (Harding, Griffin, Awwal, Alom, \& Scoular, 2017). (Hesse, Care, Buder, Sassenberg, \& Griffin, 2015) mengusulkan kerangka kerja pemecahan masalah kolaboratif yang terdiri dari keterampilan sosial dan kognitif. Keterampilan sosial diklasifikasikan; Partisipasi (aksi, interaksi, penyelesaian tugas), pengambilan perspektif (respon adaptif, kesadaran audiens), dan peraturan sosial (negosiasi, evaluasi,memori transaktif, inisiatif tanggung jawab), sementara keterampilan kognitif diklasifikasikan sebagai pengaturan tugas (analisis masalah, penetapan tujuan, mengolah data/sumber, fleksibilitas dan ambiguitas, pengumpulan informasi, sistematis) belajar dan membangun pengetahuan (menghubungkan, kontijensi, pengujian hipotesis) (Harding et al., 2017). Oleh karena itu, LKM berbasisis pemecahan masalah kolaboratif yang didesain diharapkan dapat memfasilitasi mahasiswa untuk mengembangkan keterampilan kogitif dan keterampilan social yang mereka miliki.

\subsection{Hasil AnalisisAngket}

Angket yang diberikan kepada 9 mahasiswa terdiri dari angket keterbacaan LKM dan komponen pemecahan masalah kolaboratif. Hasil analisis angket dapat dilihat pada Gambar 2 dibawah ini. 


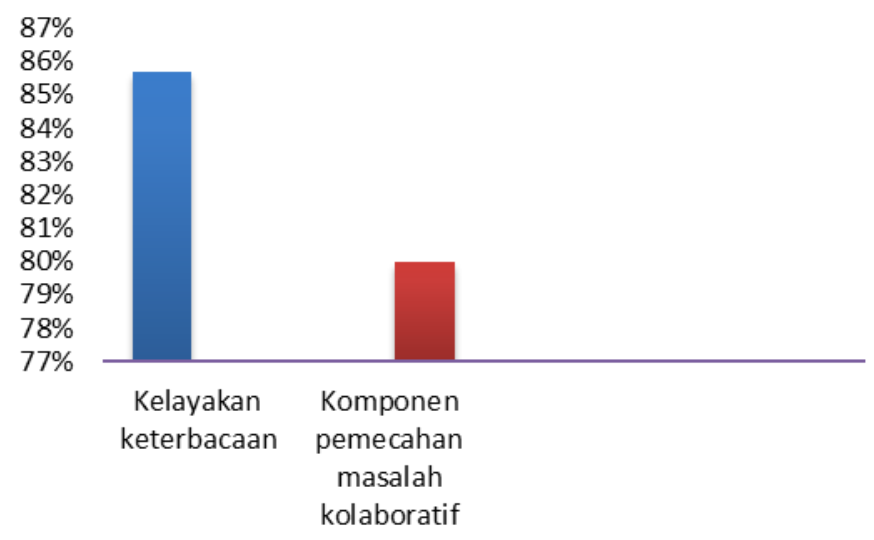

Gambar 2. Hasil analisis angket.

Lembar penilaian LKM oleh mahasiswa terdiri dari 2 elemen, yaitu kelayakan keterbacaan dan komponen pemecahan masalah kolaboratif. Hasil penilaian mahasiswa terhadap LKM disajikan pada Gambar 2 menunjukkan persentase kelayakan keterbacaan LKM sebesar 85,7 $\%$ yang berarti sangat baik dan persentase unsure komponen pemecahanmasalah kolaboratif sebesar $80 \%$ berarti baik. Adapun alasan yang diberikan beberapa mahasiswa antara lain, ada beberapa konsep pada LKM yang diberikan yang belum mereka pelajari, perlunya penambahan waktu sekitar 5 menit untuk memaksimalkan dalam pemecahan masalah. Lembar kerja berbasis pemecahan masalah juga memberikan ruang untuk mengembangkan ide-ide dalam memecahkan masalah, baik melalui individu maupun kelompok (Purwanto, 2017). Beberapa indicator kelayakan keterbacaan terdiri dari aspek bahasa, kejelasan petunjuk kegiatan, kejelasan pertanyaan, dan kesesuain isi dengan petunjuk sedangkan pada komponenen pemecahan masalah kolaboratif terdiri dari Aspek partisipasi (kerja sama dalam kelompok), proses pemecahan masalah bersama, ketercukupan waktu, tingkat kesulitan konsep termodinamika.

\section{KESIMPULAN DAN SARAN}

\subsection{Kesimpulan}

Berdasarkan hasil analisis data angket keterbacaan LKM dan komponen pemecahan masalah kolaboratif maka LKM yang dikembangkan pada katergori sangat baik. Hal ini menunjukkan bahwa LKM dapat digunakan sebagai media untuk memfasilitasi dan mengarahkan mahasiswa untuk meningkatkan kemampuan pemecahan masalah. Beberapa komentar dari mahasiswa yang mengisi angket yaitu perlu penambahan waktu dalam penyelesaian masalah dan konsep-konsep yang disajikan dalam LKM lebih disesuaikan dengan apa yang sudah mereka pelajari sebelumnya.

\subsection{Saran}

Pengembangan LKM berbasis pemecahan masalah kolaboratif sebaiknya desain LKM dibuat lebih kompleks yaitu kemampuan yang akan dilatihkan tidakhanya kemampuan pemecahan masalah melainkan kemampuanberpikir refleksi, berpikir kreatif dan keterampilan lainnya, LKM juga harus mempertimbangkan alokasi waktu dan analisis konsep termodinamika yang sesuai dengan capaian pemebelajaran, tujuan pembelajaran dan kemampuan yang harus dicapai oleh mahasiswa. 


\section{DAFTAR PUSTAKA}

Akpınar, E. (2014). The use of interactive computer animations based on POE as a presentation tool in primary science teaching. Journal of Science Education and Technology. 23 pp 527-537. http://dx.doi.org/10.1007/s10956-013-9482-4

Häkkinen, P., Järvelä, S., Mäkitalo-Siegl, K., Ahonen, A., Näykki, P., \& Valtonen, T. (2017). Preparing teacher-students for twenty-first-century learning practices (PREP 21): a framework for enhancing collaborative problem-solving and strategic learning skills. Teachers and Teaching, 23(1), 25-41. https://doi.org/10.1080/13540602.2016.1203772.

Harding, S.-M. E., Griffin, P. E., Awwal, N., Alom, B. M., \& Scoular, C. (2017). Measuring Collaborative Problem Solving Using Mathematics-Based Tasks. AERA Open, 3(3), 233285841772804. https://doi.org/10.1177/2332858417728046

Hesse, F., Care, E., Buder, J., Sassenberg, K., \& Griffin, P. (2015). A Framework for Teachable Collaborative Problem Solving Skills. In Assessment and Teaching of 21st Century Skills (pp. 37-56). Dordrecht: Springer Netherlands. https://doi.org/10.1007/978-94-017-9395-7_2

Puranti widoretno, n. F. D. B. (2014). Pengembangan LKS dengan Pembelajaran Berbasis Masalah Pada Materi Diagram Gaya Normal, Gaya Lintang, dan Momen Di Kelas X Tgb 1 SMK Negeri 1 Sidoarjo. Jurnal Kajian Pendidikan Teknik Bangunan, $3(1 / \mathrm{JKPTB} / 14)$

Richey, R, \& Klein, J D. (2007). Design and development research: Methods, strategies, and issues. Mahwah, New Jersey: London

Saregar, A. (2016). Pembelajaran pengantar fisika kuantum dengan memanfaatkan media phet simulation dan LKM melalui pendekatan saintifik: Dampak pada Minat dan Penguasaan Konsep Mahasiswa. Jurnal Ilmiah Pendidikan Fisika Al-Biruni, 5(1), 5360 . 